\title{
PENGEMBANGAN MOBILE LEARNING BERBASIS ANDROID DENGAN METODE KUMON UNTUK MATERI INTEGRAL TAK TENTU
}

\author{
${ }^{1)}$ Eka Nur Ainiy, ${ }^{2)}$ Syita Fatih 'Adna, ${ }^{3)}$ Muhamad Najibufahmi \\ Universitas Pekalongan, Jalan Sriwijaya No. 1 Pekalongan \\ syita.fatih@gmail.com
}

\begin{abstract}
Received :

This studied developed Android-based mobile learning with the Kumon method $19 / 05 / 2021$ for Indefinite Integral material. This studied aims to produce a product in the form of android-based mobile learning which uses the Kumon method steps and

Accepted : test the level of validity and practicality to be used as a learning medium on

$14 / 06 / 2021$ indeterminate integral material. The research method used in this research is the Plomp method.The results of this development research was in the form of Android-based mobile learning with the Kumon method for indefinite integral

Published : material through validation test with an average presentation of $82 \%$ according 01/07/2021 to 8 validators and a practicality test with an average percentage of $67 \%$ according to 33 students SMA N 1 Bojong class XII IPA 1. From the results of this studied it can be concluded that Android-based mobile learning with the Kumon method for indefinite integral material meets the requirements with very valid and practical quality to be used as a learning medium that could be used with android in the learning process class in person or online independently on indefinite integral material.
\end{abstract}

Keywords: Development, Mobile Learning, Android, Kumon Method, Indefinite Integral, Lectora Inspire

\begin{abstract}
Abstrak
Penelitian ini mengembangkan mobile learning berbasis android dengan metode Kumon untuk materi integral tak tentu. Penelitian ini bertujuan untuk menghasilkan produk berupa mobile learning berbasis android yang di dalamnya menggunakan langkah-langkah metode Kumon dan menguji tingkat validitas serta kepraktisannya untuk digunakan sebagai media pembelajaran pada materi integral tak tentu. Metode penelitian yang digunakan adalah metode Plomp. Hasil dari penelitian pengembangan ini berupa mobile learning berbasis android dengan metode Kumon untuk materi integral tak tentu yang melalui analisis validasi dengan presentasi rata-rata sebesar $82 \%$ menurut 8 validator dan uji kepraktisan dengan presentase rata-rata $67 \%$ menurut 33 siswa SMA N 1 Bojong kelas XII IPA 1. Dari hasil penelitian ini dapat disimpulkan bahwa mobile learning berbasis android dengan metode Kumon untuk materi integral tak tentu ini memenuhi persyaratan dengan kualitas cukup valid dan praktis untuk digunakan sebagai media pembalajaran yang dapat digunakan dengan android dalam proses pembelajaran dikelas secara langsung maupun daring secara mandiri pada materi integral tak tentu.
\end{abstract}

Kata Kunci: Pengembangan, Mobile Learning, Android, Metode Kumon, Integral Tak Tentu, Lectora Inspire

\section{Pendahuluan}

Perkembangan IPTEK memiliki pengaruh yang besar dalam berbagai bidang kehidupan manusia seperti sosial, ekonomi, budaya, dan pendidikan. Perkembangan IPTEK yang semakin pesat menuntut kita agar selalu melakukan pembaharuan dalam pemanfaatan hasil teknologi terutama di bidang pendidikan (Syita Fatih 'Adna dan Dewi Mardhiyana, 2019:7). Salah satunya adalah munculnya konsep mobile 
learning. Konsep mobile learning dengan menggunakan perangkat mobile dianggap dapat memudahkan siswa dalam membawa perangkat ini kapanpun dan kemanapun karena dianggap lebih fleksibel untuk digunakan siswa sebagai media pembelajaran (Ibrahim \& Ishartiwi, 2017:82). Salah satu perangkat mobile yang dapat dikembangkan sebagai media pembelajaran mobile learning dan dapat dengan mudah dibawa kemana saja adalah Android (Safaat, 2012: 1). Mobile learning berbasis android menggabungkan dan menghubungkan antara konten pendidikan dan teknologi. Kemajuan teknologi dewasa ini juga menghasilkan beberapa aplikasi yang bermanfaat dalam dunia pendidikan. Salah satunya adalah aplikasi lectora inspire yang dapat digunakan untuk membuat sebuah media pembelajaran intekraktif berbasis android yang menarik.

Media pembelajaran merupakan sebuah alat bantu atau perantara dalam penyampaian materi pembelajaran yang bisa memberikan pengetahuan serta pengalaman lebih terhadap siswa. Penggunaan media pembelajaran yang menarik akan meningkatkan motivasi dan minat siswa untuk belajar, pada akhirnya akan membuat siswa memahami materi yang diberikan (Setyadi dan Qohar, 2017:1). Adanya perkembangan media pembelajaran dengan android sebagai sarana pembelajaran akan menjadikan android lebih tepat guna, bermanfaat, dan memberikan kemudahan dalam mengakses pembelajaran bagi siswa maupun guru. Terlebih pengguna android dikalangan pelajar sudah semakin banyak sehingga siswa bisa menggunakannya secara bijak dan positif.

Matematika yang merupakan salah satu cabang ilmu pengetahuan yang harus dipelajari oleh setiap jenjang pendidikan (Junaidi dan Arisna, 2013:1), bertujuan pembelajaran matematika adalah agar siswa memiliki kemampuan memahami konsep matematika, menjelaskan keterkaitan antar konsep, mengaplikasikan konsep secara luwes, akurat, efisien, dan tepat (Burhan., dkk, 2014:6). Pemahaman konsep merupakan bagian penting dalam mempelajari matematika. Jadi dalam belajar matematika siswa harus memahami konsep terlebih dahulu, siswa tidak hanya mengenal dan mengetahui tetapi mampu mengungkapkan kembali konsep dalam bentuk yang lebih mudah dimengerti, mampu menggunakan konsep untuk menyelesaikan masalah dengan baik, cara penyelesaian yang tepat dan mampu mengaplikasikan pembelajaran tersebut kedunia nyata.

Berdasarkan hasil wawancara dengan guru dan angket investigasi awal siswa di SMA N 1 Bojong, diperoleh informasi bahwa sebagian besar guru menyampaikan materi matematika dengan menggunakan metode caramah dan demonstrasi, guru masih menggunakan bahan ajar berupa buku paket dan LKS (Lembar Kerja Siswa). Sejak dilaksanakannya pembelajaran daring akibat pandemi virus covid-19, hal ini membuat siswa harus belajar mandiri dengan fasilitas sumber belajar video pembelajaran yang diperoleh dari guru dan mengerjakan latihan soal yang ada dalam LKS. Banyak siswa yang mengeluh dan merasa kesulitan untuk belajar matematika secara daring, siswa berharap dapat belajar kembali secara langsung dikelas. Hal ini berakibat pada kesulitan siswa untuk memahami konsep dengan baik, jika konsep belum bisa dikuasai maka siswa tersebut juga akan kesulitan menyelesaikan masalah pada soal yang diberikan. 
Gambaran permasalahan tersebut menunjukkan bahwa pembelajaran matematika perlu diperbaiki guna meningkatkan pemahaman siswa terhadap konsep matematika. Salah satu cara untuk mengatasinya dengan menerapkan metode pembelajaran matematika dengan metode Kumon. Menurut Huda (2014:189) Metode Kumon merupakan metode belajar perseorangan. Ciri khas dari metode Kumon itu sendiri adalah siswa diberi tugas untuk menyelesaikan masalah mulai dari level yang dapat dikerjakannya dengan mudah sampai paling susah, tugas yang akan diberikan telah didesain sedemikian rupa sehingga siswa dapat memahami sendiri bagaimana menyelesaikan soal-soal, jika siswa terus belajar dengan kemampuannya sendiri, siswa akan mengejar bahan pelajaran yang setara dengan tingkatan kelasnya bahkan maju melampauinya.

Penerapan metode kumon dalam pembelajaran Matematika sudah diteliti oleh Widiawati, N dan Deddy Sofyan pada tahun 2015. Hasil yang diperoleh adalah prestasi belajara matematika siswa yang mendapatkan metode pembelajaran Kumon lebih baik dibandingkan dengan siswa yang mendapat metode pembelajaran konvensional. Selain itu, penelitian yang berkaitan dengan penerapan metode Kumon dalam pembelajaran juga dilakukan oleh Putri, Rachmawati tahun 2017. Namun, penggunaan metode Kumon dalam kelas besar dirasa kurang efektif ketika harus banyak melakukan pengoreksian. Sebagai inovasi dalam penelitian sekaligus mengurangi ketidakefektifan dalam pengoreksian, penerapan metode Kumon disajikan menggunakan mobile learning dengan aplikasi Lectora Inspire. Menurut Ala'raf, H. M dalam penelitiannya di tahun 2017, penggunaan Lectora Inspire efektif dalam pembelajaran.

\section{Metode Penelitian}

Metode penelitian yang digunakan adalah metode pengembangan (Research and Development/R\&D). Penelitian ini mengadaptasi model pengembangan Plomp yang terdiri dari fase investigasi awal, fase desain, fase realisasi/konstruksi, fase tes, evaluasi dan revisi, dan fase implementasi (Hobri, 2010:17). Karena keterbatasan waktu dan pembatasan penelitian, maka pada peneliti mereduksi model pengembangan Plomp dengan membatasi hanya sampai tahap fase tes, evaluasi dan revisi.

\section{a. Fase Investigasi Awal}

Fase ini terfokus pada pengumpulan data dan analisis informasi, mendefinisikan masalah dan merencanakan kegiatan selanjutnya, meliputi pengumpulan informasi tentang permasalahan pembelajaran matematika terdahulu atau yang tengah berjalan dan merumuskan rasional pemikiran pentingnya pengembangan produk, mengidentifikasi dan mengkaji teori-teori yang mendasari pengembangan yang dilakukan (Hobri, 2010:19). Fase ini merupakan analisis kebutuhan siswa terkait pengembangan media. Untuk memperoleh data pada fase ini diperlukan metode wawancara dan metode angket. Wawancara dilakukan kepada beberapa guru Matematika SMA N 1 Bojong sedangkan angket diberikan kepada siswa kelas XII IPA I. 
b. Fase Desain

Kegiatan pada fase ini lebih difokuskan kepada hasil yang telah didapatkan pada fase investigasi awal, kemudian dirancang solusinya (Rochmad, 2012:66). Pada fase ini dilakukan analisis flow chart dan storyboard dan analisis instrumen penelitian.

c. Fase Realisasi/Kontruksi

Fase ini adalah fase lanjutan fase desain. Pada tahap ini dihasilkan prototype I sebagai realisasi hasil perancangan model (Hobri, 2010:22).

\section{d. Fase Tes, Evaluasi dan Revisi}

Pada fase ini dipertimbangkan kualitas solusi yang telah dikembangkan dan dibuat keputusan yang berkelanjutan didasarkan pada hasil pertimbangan. Evaluasi merupakan proses mengumpulkan, memproses dan menganalisis informasi secara sistematis untuk menilai solusi yang telah dibuat. Pada fase ini dilakukan 2 kegiatan utama, yaitu (1) kegiatan validasi, dan (2) kegiatan uji coba prototype II terbatas (Hobri, 2010 :23). Validasi merupakan pengesahan atau pengujian kebenaran atas sesuatu. Instrumen yang digunakan berupa angket validasi. Prototype yang sudah dihasilkan pada fase realisasi divalidasi oleh validator. Kemudian hasil validasi prototype I yang telah direvisi adalah prototype II. Uji coba prototype II dilaksanakan dengan tujuan untuk mengetahui bagaimana kepraktisan mobile learning berbasis android menggunakan metode Kumon pada materi integral tak tentu pada kelas terbatas. Setelah produk diujicobakan, angket respon dibagikan ke siswa agar dapat mengetahui kepraktisan dari mobile learning yang dikembangkan, selanjutnya produk direvisi sesuai dengan perbaikan yang dibutuhkan. Revisi dari prototype II adalah prototype final.

\section{Hasil dan Pembahasan}

a. Fase Investigasi Awal

Pada fase ini dilakukan analisis untuk memperoleh informasi dengan metode wawancara dan angket di SMA N 1 Bojong. Wawancara dilakukan dengan narasumber guru dan siswa, sedangkan angket diberikan kepada siswa sehingga diperoleh hasil analisis berupa informasi sebagai berikut :

1) Analisis Ujung Depan

Kurikulum yang berlaku di SMA N 1 Bojong adalah kurikulum 2013. Metode pembelajaran yang sering digunakan dikelas adalah metode ceramah dan demonstrasi. Akibat adanya pandemi virus covid-19, diberlakukan proses pembelajaran secara daring, sehingga pembelajaran menggunakan video dan latihan soal pada LKS, belum digunakan metode dan media pembelajaran lain. Dalam penelitian ini diberikan solusi untuk menggunakan metode Kumon, yaitu metode yang berpusat pada siswa dan melatih kemampuan siswa secara individual untuk belajar mandiri, sehingga sesuai dengan pembelajaran secara daring. Menggunakan mobile learning berbasis android dapat memfasilitasi siswa belajar dimana dan kapanpun.

2) Analisis Siswa

Motivasi belajar matematika masih kurang, hal ini tergantung guru yang mengajar dan materi yang diberikan. Adanya pembelajaran daring menggunakan video dan 
pemberian tugas pada LKS dirasa masih belum bisa menggantikan pembelajaran langsung serta belum bisa membuat siswa dapat memahami materi dengan baik. Siswa merasa kesulitan untuk belajar secara daring dan menyelesaikan soal yang ada dalam LKS. Dalam penelitian ini diberikan solusi dengan membuat mobile learning sebagai media pembelajaran menggunakan metode Kumon yaitu belajar perlevel mulai dari paling mudah sampai paling susah, sehingga siswa tertarik untuk belajar dan memudahkan siswa untuk belajar dengan kemampuan yang dimiliki. Dengan latihan soal dapat melatih siswa untuk menyelesaikan masalah, disediakan pula penyelesaian sehingga siswa dapat belajar dan mengetahui penyelesaian yang tepat, serta dengan syarat lanjut level dapat memicu semangat siswa untuk belajar dan menyelesaikannya.

3) Analisis Materi

Materi pembelajaran yang digunakan dalam penelitian ini adalah materi integral tak tentu, sesuai dengan KI dan KD maka integral tak tentu terbatas pada fungsi aljabar. Kompetensi Inti dan Kompetensi Dasar yang digunakan di SMA N 1 Bojong mengacu pada Permendikbud nomor 37 tahun 2018. Berikut pada Gambar 1 rincian materi integral tak tentu fungsi aljabar yang diberikan:

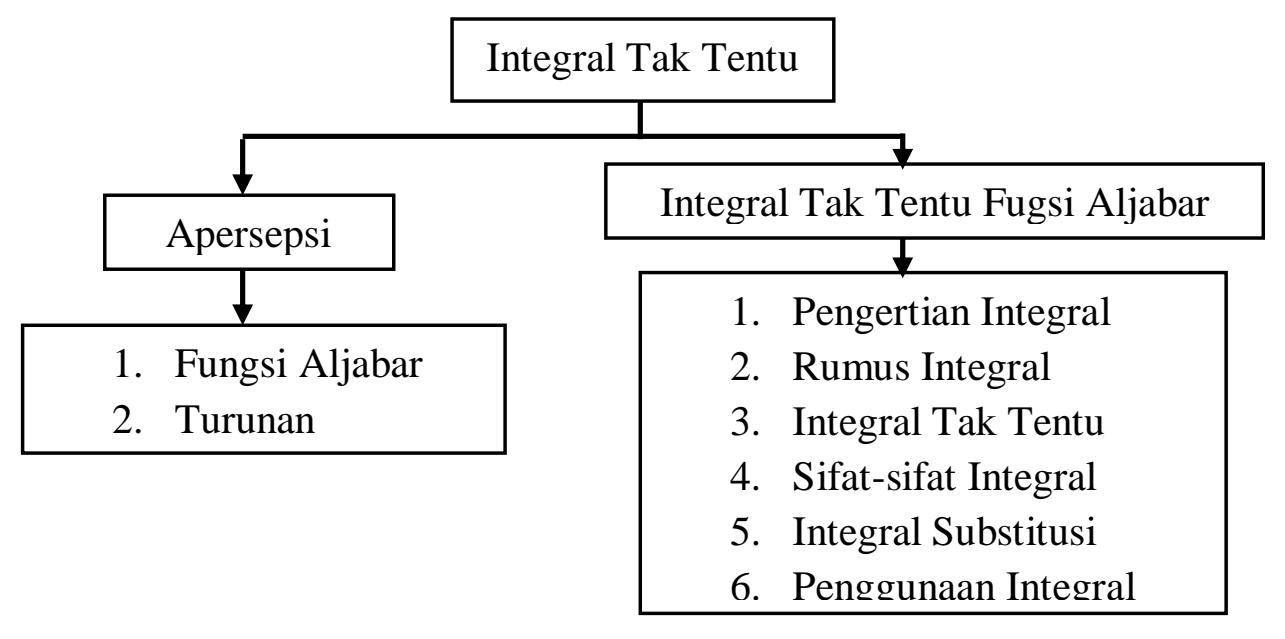

b. Fase Desain

Gambar 1. Rincian Materi Integral Tak Tentu

Berdasarkan hasil analisis dari fase investigasi awal, selanjutnya dilakukan analisis tentang rancangan mobile learning yang telah dikembangkan, sebagai berikut:

a. Analisis Flow Chart dan Storyboard dari mobile learning

1) Flow Chart

Model flow chart yang dibuat adalah tipe drills disesuaikan dengan metode Kumon, sebagai berikut : 


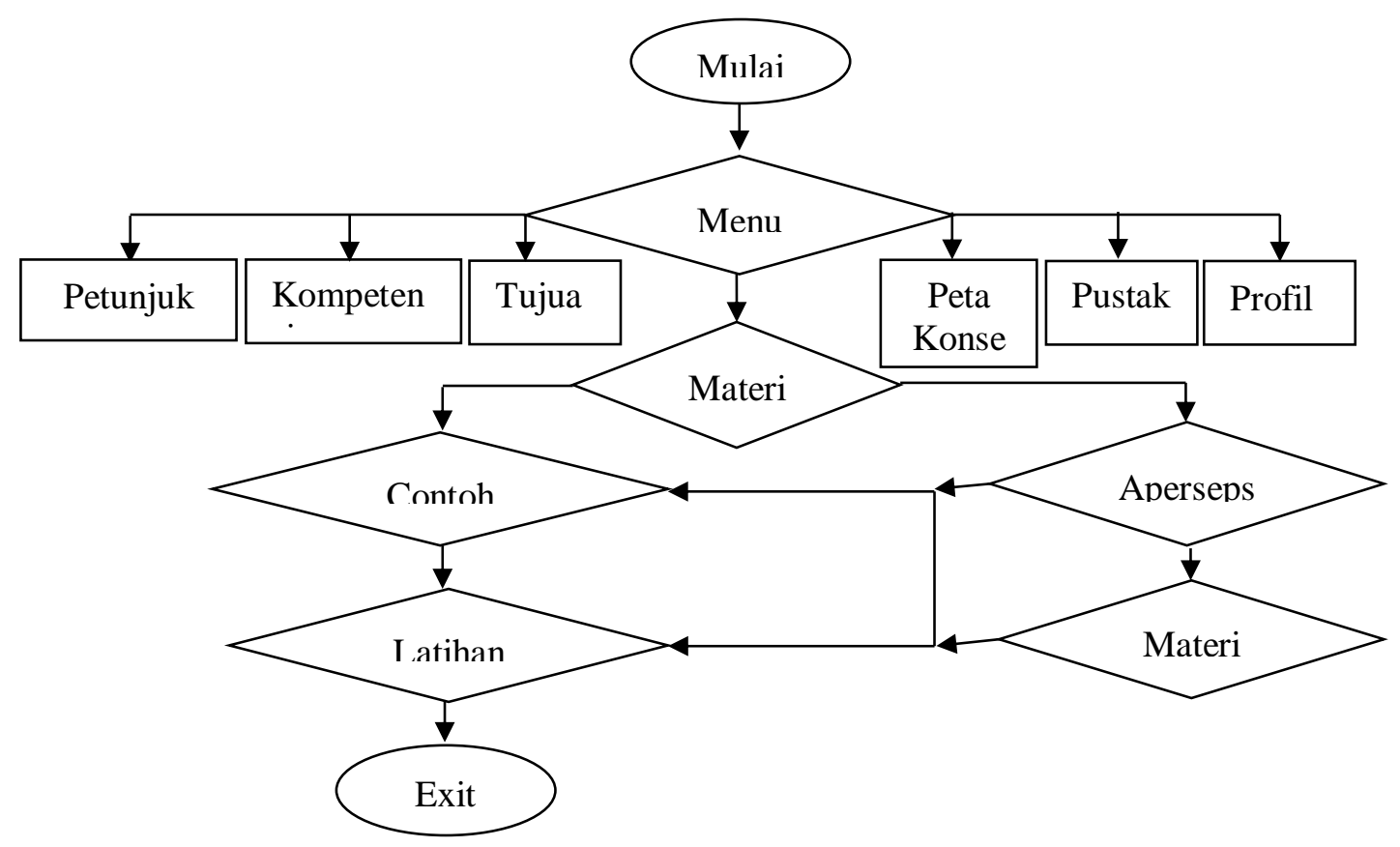

Gambar 2. Flowchart Mobile Leraning

2) Storyboard

Storyboard dibuat untuk memudahkan penggabungan komponenkomponen mobile learning yang dikembangkan. Untuk lebih jelasnya berikut ini storyboard dalam bentuk tabel 1 yang telah dibuat,

Tabel 1. Storyboard Mobile Learning

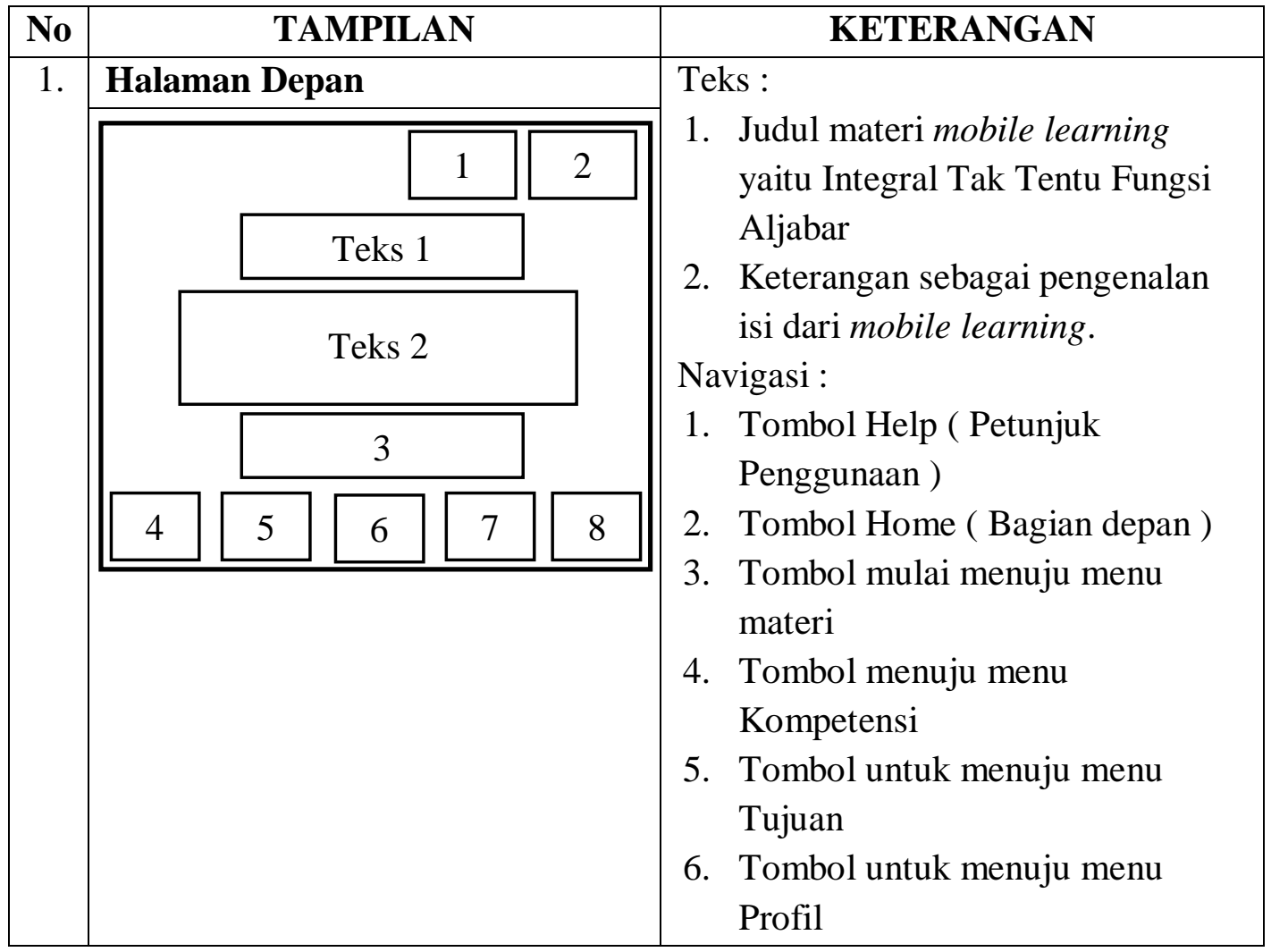




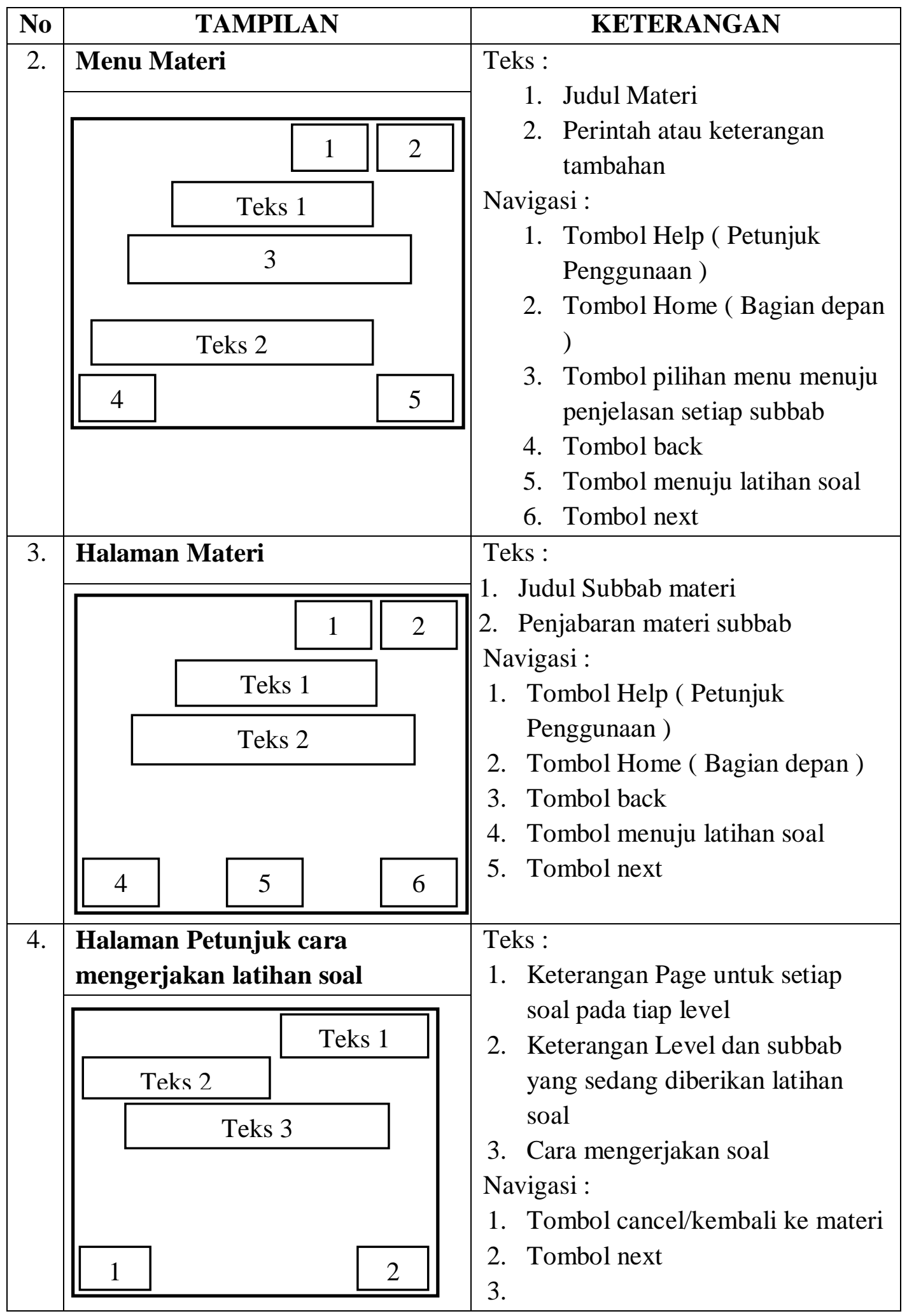




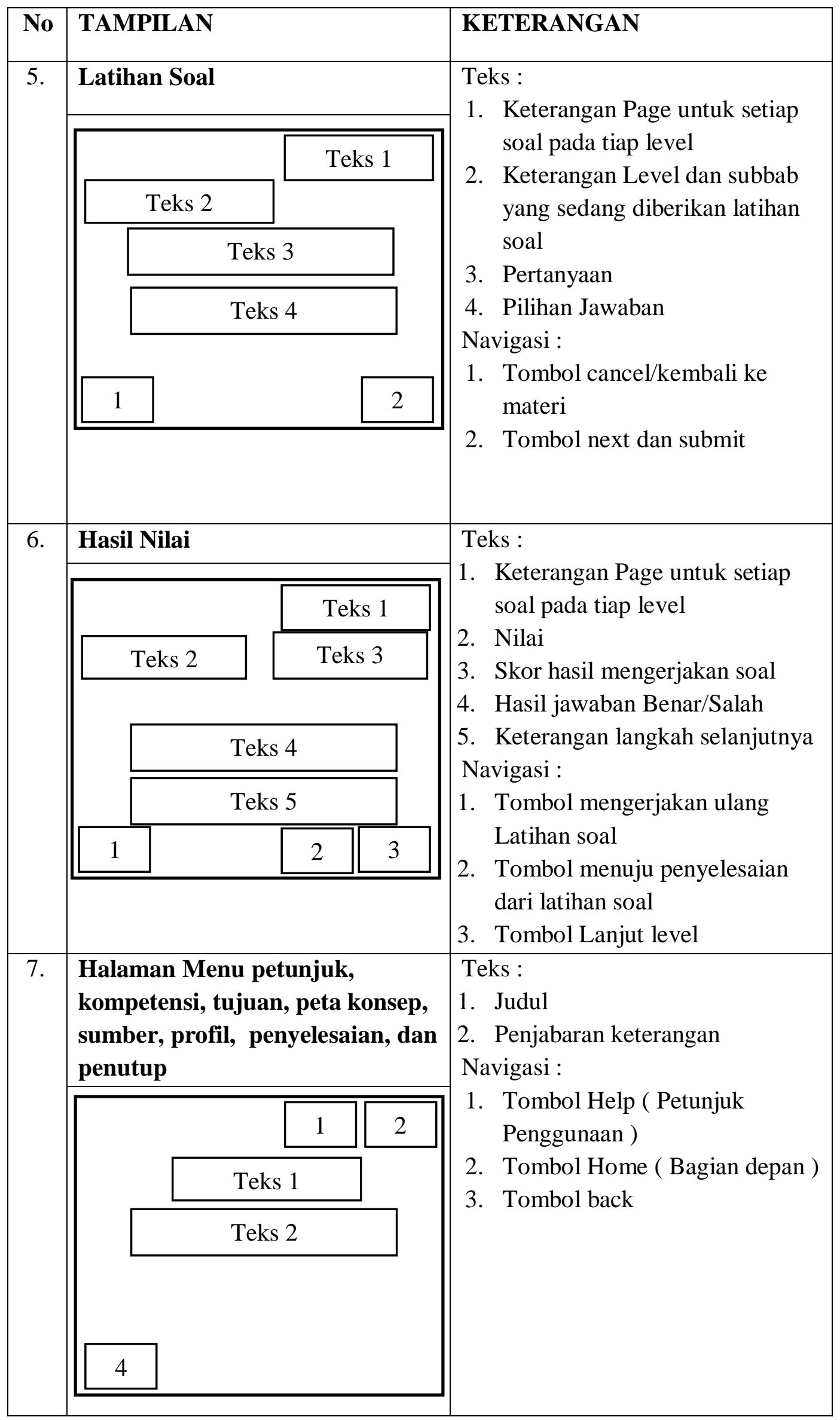


b. Analisis Instrumen Penelitian

Instrumen penelitian meliputi angket investigasi awal, angket validasi, dan angket respon siswa dibuat menggunakan google form sehingga dihasilkan link yang dapat dibagikan.

1) Angket Investigasi Awal

Lembar angket investigasi awal bertujuan untuk mengetahui informasi tentang permasalahan pembelajaran matematika terdahulu atau yang tengah berjalan yang berkaitan dengan kebutuhan pentingnya pengembangan media.

2) Angket Validator

Lembar angket validasi mobile learning bertujuan untuk memvalidasi mobile learning yang dikembangkan. Desain bagianbagian angket validator terdiri dari beberapa komponen yaitu identitas, petunjuk pengisian, penilaian, kesimpulan dan saran.

3) Angket Respon Siswa

Lembar respon siswa pada penelitian ini berisi tentang keterkaitan terhadap komponen senang, menarik, bersemangat, dan memudahkan. Desain bagian-bagian angket respon siswa terdiri dari identitas, petunjuk pengisian, penilaian,kesimpilan dan saran.

c. Fase Realisasi/Kontruksi

Pada fase ini dilakukan pembuatan mobile learning dan instrumeninstrumen yang dibutuhkan sebagai lanjutan dari fase desain. Hasil dari fase realisasi ini adalah mobile learning berbasis android dengan metode Kumon untuk materi integral tak tentu dalam bentuk link yang dapat diakses secara online dan instrumen-instrumen yang dibutuhkan dalam penelitian ini berupa google form dalam bentuk link. Mobile learning hasil dari fase ini adalah prototype I. Berikut merupakan hasil pengembangan mobile learning dan intrumen penelitian, antara lain :

1) Pengembangan mobile learning, pada tahap ini dihasilkan link https://s.id/lo5G- hasil dari pengembangan mobile learning

2) Angket validator, pada tahap ini dihasilakan link angket validator https://s.id/li7fA

3) Lembar angket respon siswa, pada tahap ini dihasilkan link angket respon siswa https://s.id/paxlC

d. Fase Tes, Evaluasi dan Revisi

Pada fase ini dilakukan dua kegiatan utama, yaitu : 1) Kegiatan validasi, 2) Kegiatan uji coba prototype II terbatas. Berikut uraian pada fase ini adalah kegiatan validasi dan uji coba prototype terbatas.

1) Kegiatan validasi

Sebelum instrument penelitian digunakan, perlu dilakukan validasi oleh dosen pembimbing agar diketahui tingkat kelayakan instrument tersebut untuk digunakan, proses ini dilakukan dengan memberikan Lembar 
validasi angket validasi dan Lembar validasi angket respon siswa atau memberikan link https://s.id/lzmMP dan https://s.id/lzsfO kepada dosen pembimbing dengan menilai tingkat relevansinya. Kemudian untuk proses validasi mobile learning dilakukan dengan memberikan link mobile learning https://s.id/lo5G- serta link angket validasi https://s.id/li7fA kepada validator untuk diisi berdasarkan mobile learning yang sudah dibuat. Saransaran dari validator tersebut dijadikan bahan untuk merevisi instrument penelitian dan prototype I mobile learning sehingga menghasilkan prototype II mobile learning. Adapun validator terdiri dari 3 dosen dan 5 guru.

a) Revisi Instrumen Penelitian

Dalam proses validasi angket validasi dan angket respon siswa untuk mengetahui relevansi instrumen penelitian yang digunakan dan mengetahui kekurangan dari intrumen tersebut. Dosen pembimbing Ibu Syita Fatih Adna, S.Pd., M.Sc., Bapak M. Najibufahmi, M.Sc dan validator Ibu Nur Baiti Nasution, S.Pd., M.Sc. memberikan saran untuk perbaikan instrumen angket validasi dan instrumen angket respon siswa yang disajikan pada tabel 2 untuk selanjutnya dilakukan revisi, sebagai berikut :

Tabel 2. Saran Validator Terhadap Instrumen Penelitian

\begin{tabular}{llr}
\hline No & \multicolumn{1}{c}{ Saran } & Tindak Lanjut \\
\hline 1. & Aspek evaluasi tidak perlu & Sudah dilakukan \\
2. & $\begin{array}{l}\text { Pernyataan pada angket validasi yang di nilai belum } \\
\text { mengarah ke metode Kumon }\end{array}$ & Sudah dilakukan \\
3. & $\begin{array}{l}\text { Pernyataan nomer 1 sama dengan nomer 2, pernyataan } \\
\text { nomer 5 dan nomer 9 juga sama pada instrumen angket }\end{array}$ & Sudah dilakukan \\
& respon siswa & \\
\hline
\end{tabular}

b) Revisi Mobile Learning

Setelah dilakukan proses vaidasi oleh validator yang terdiri dari 3 Dosen Unikal yaitu Ibu Nur Baiti Nasution, S.Pd., M.Sc., Ibu Nurina Hidayah, M.Pd., Bapak Wahyu Hidayat, M.Pd., serta Guru SMA N 1 Bojong yaitu Bapak Sri Achmadi, S.Pd. Mat., Ibu Wirdatul Badiah, S.Pd., Bapak Asyifa Mulia Himawan, S.Pd., Bapak M. Khusni Mubarok, S.Pd., dan Ibu Dina Radlia, S.Pd. untuk mengetahui kekurangan dari produk mobile learning yang dikembangkan. Berikut saran dari validator disajikan dalam Tabel 3 untuk selanjutnya dilakukan revisi dibeberapa bagian dalam mobile learning sesuai saran validator yang memungkinkan untuk direvisi sehingga dihasilkan link mobile learning baru yaitu https://s.id/pawD1 . 
Tabel 3. Saran Validator Terhadap mobile learning

\begin{tabular}{|c|c|c|}
\hline No & Saran & Tindak Lanjut \\
\hline 1 & Efektivitas pengecoh pada latihan soal perlu ditingkatkan. & Sudah dilakukan \\
\hline 2 & ngkan menjadi APK & Tidak dilakukan \\
\hline 3 & $\begin{array}{l}\text { Pemilihan background dapat menyesuaikan dengan tahap } \\
\text { perkembangan anak usia SMA }\end{array}$ & Sudah dilakukan \\
\hline 4 & $\begin{array}{l}\text { Dapat ditambahkan beberapa soal HOTS dan soal } \\
\text { penerapan dalam kehidupan sehari-hari }\end{array}$ & kan \\
\hline 5 & $\begin{array}{l}\text { a diberikan juga soal-soal uraian untuk } \\
\text { h mana siswa memahami materi }\end{array}$ & Tidak dilakukan \\
\hline 6 & $\begin{array}{l}\text { Opsi jawaban untuk tingkat SMA biasa menggunakan } \\
\text { opsi } 5 \text { jawaban }\end{array}$ & dilakukan \\
\hline 7 & $\begin{array}{l}\text { Sebaiknya disetting tidak harus mendapatkan nilai } 100 \\
\text { untuk dapat dapat membuka penyelesaian }\end{array}$ & Sudah dilakukan \\
\hline 8 & $\begin{array}{l}\text { Untuk petunjuk bisa ditambahi keterangan mode } \\
\text { landscape }\end{array}$ & Sudah dilakukan \\
\hline 9 & Soal menjodohkan agar diberi keterangan penjelas & Sudah dilakukan \\
\hline
\end{tabular}

Hasil uji validitas mobile learning berbasis android menggunakan metode kumon untuk materi integral tak tentu mencapai $81,72 \%$. Hal ini menunjukkan bahwa mobile learning sangat valid dengan empat aspek yaitu aspek format media, aspek bahasa, aspek materi, dan aspek soal. Berdasarkan gambar 3 dapat disimpulkan bahwa hasil rata-rata setiap aspek validasi memenuhi kriteria kevalidan, berikut adalah grafik hasil analisis validasi dari 8 validator dari setiap aspek :

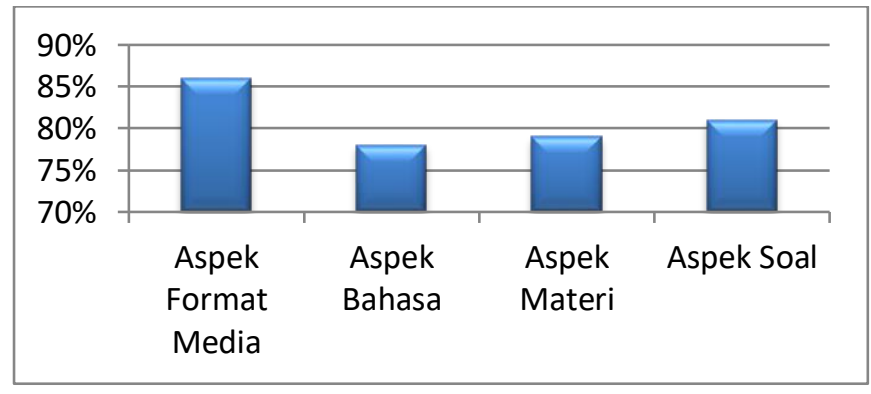

Gambar 3. Hasil Uji Validasi

2) Kegiatan uji coba prototype II terbatas

Uji coba terbatas dilaksanakan pada hari Kamis tanggal 13 Agustus 2020, dilakukan dengan membagikan link alamat mobile learning https://s.id/pawD1 kepada siswa secara daring melalui grup wa kelas XII MIPA 1 untuk digunakan belajar integral tak tentu. Kemudian diberikan link angket respon siswa https://s.id/paxlC untuk diisi oleh siswa sesuai dengan mobile learning berbasis android dengan metode Kumon yang sudah diterima siswa. Hasil uji kepraktisan pada siswa SMA N 1 Bojong kelas XI IPA 1 mencapai $67,05 \%$ penilaian secara keseluruhan aspek. Hal ini menunjukkan bahwa mobile learning praktis. Berdasarkan gambar 4 dapat disimpulkan bahwa hasil rata-rata setiap aspek yaitu aspek senang, aspek 

Vol. 9 No. 2 Bulan Juli hal. $271-284$

menarik, aspek bersemangat, dan aspek memudahkan memenuhi kriteria kepraktisan, sebagai berikut:

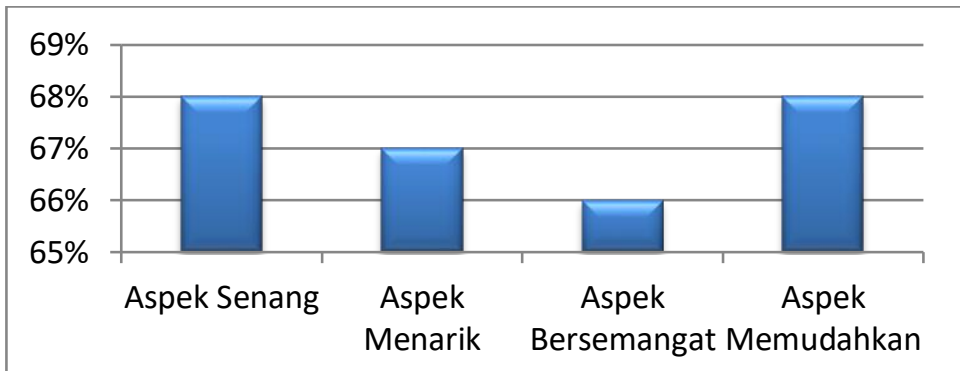

Gambar 4. Uji Kepraktisan

Berikut adalah tampilan mobile learning berbasis android menggunakan metode kumon untuk materi integral tak tentu yang telah dikembangkan:

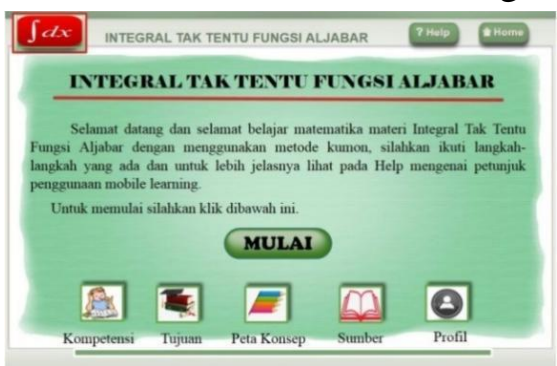

Gambar 5. Halaman Depan

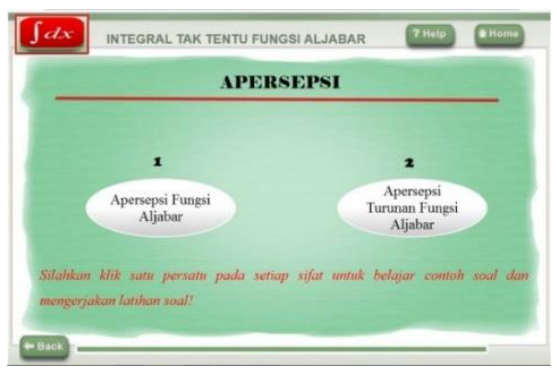

Gambar 7. Menu Apersepsi

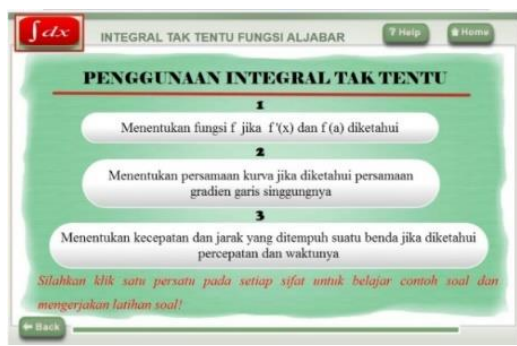

Gambar 9. Menu Penggunaan Integral

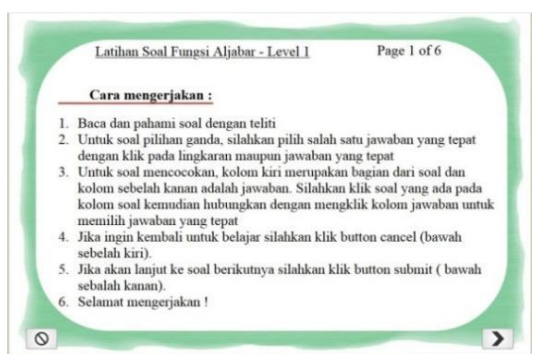

Gambar 11. Tampilan cara

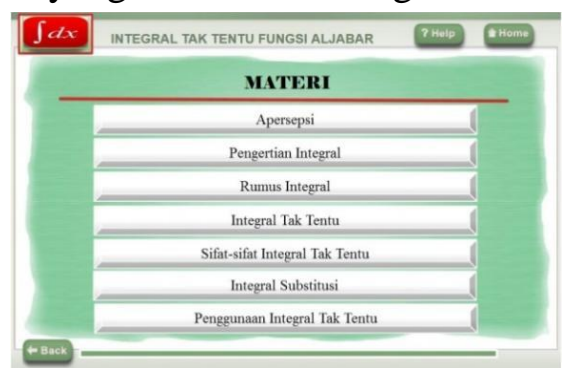

Gambar 6. Menu Materi

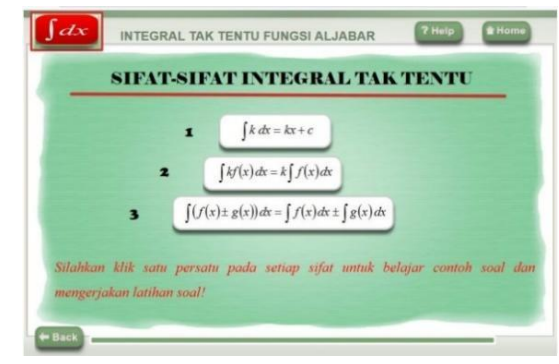

Gambar 8. Menu sifat-sifat integral

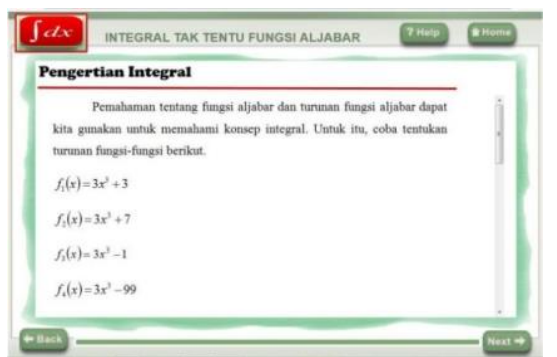

Gambar 10. Tampilan Materi

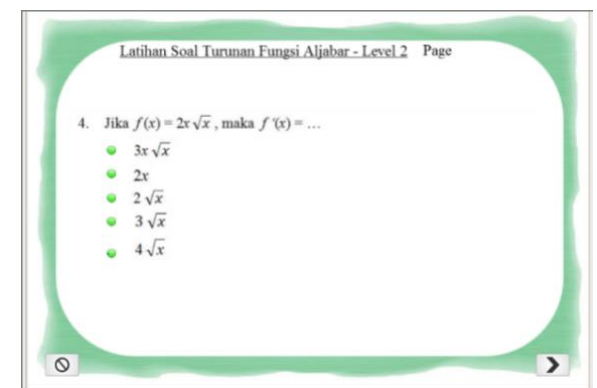


mengerjakan

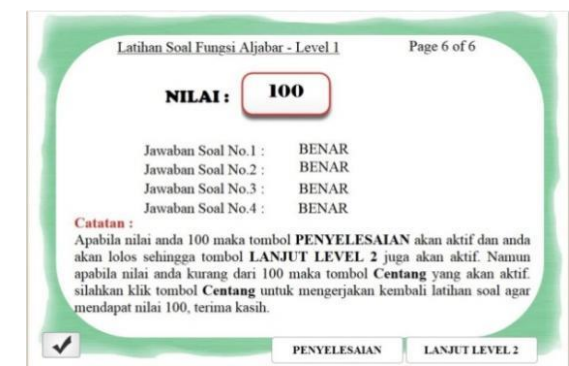

Gambar 13. Tampilan hasil nilai

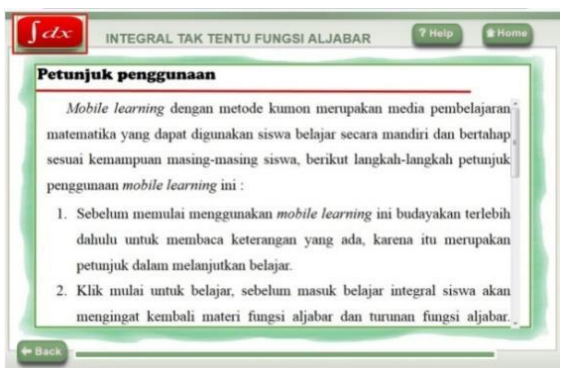

Gambar 14. Tampilan menu petunjuk
Gambar 12. Tampilan latihan soal

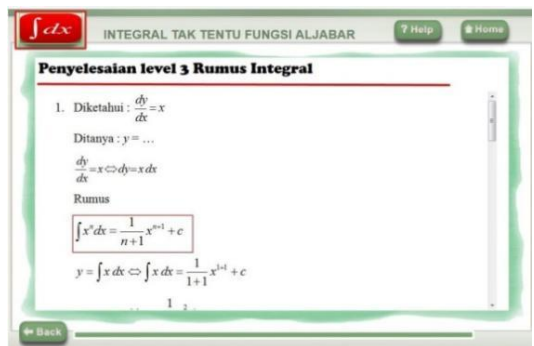

Gambar 14. Tampilan menu penyelesaian

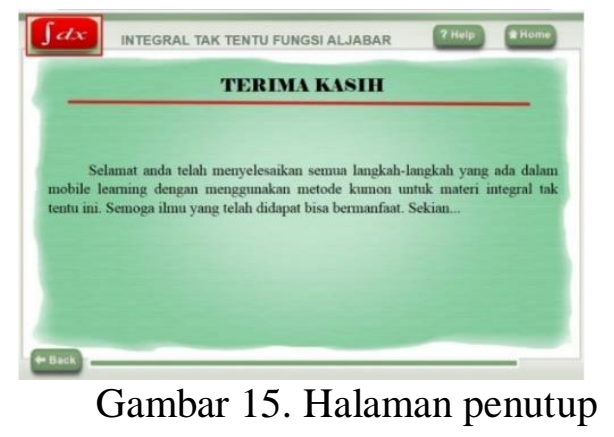

\section{Kesimpulan dan Saran}

Berdasarkan hasil validasi oleh dosen dan guru serta hasil respon siswa SMA N 1 Bojong kelas XII IPA 1 dapat disimpulkan bahwa pengembangan mobile learning berbasis android dengan metode Kumon untuk materi integral tak tentu menghasilkan rata-rata validasi $82 \%$ yang artinya sangat valid dan rata-rata kepraktisan $67 \%$ yang artinya praktis. Berdasarkan penelitian yang telah dilakukan, maka peneliti mempunyai saran perlunya diadakan penelitian lebih lanjut untuk beberapa materi pelajaran lainnya. Namun, penggunaan Lectora Inspire pada penelitian ini membutuhkan sistem jaringan internet yang stabil agar dapat diakses. Sehingga, diharapkan pada penelitian selanjutnya dapat diubah ke bentuk aplikasi yang dapat diunduh melalui playstore agar dapat diakses secara offline.

\section{Ucapan Terima Kasih}

Terima kasih kepada Universitas Pekalongan khususnya Fakultas Keguruan dan Ilmu Pendidikan prodi Pendidikan Matematika. Terima kasih kepada Bapak dan Ibu dosen pembimbing atas bimbingan dan arahannya dalam menyelesaikan penelitian ini. Terima kasih kepada Bapak Ibu dosen dan guru validator. Terima kasih kepada keluarga dan teman-teman atas dukungan dan do'a yang diberikan. Serta segenap pihak yang telah memberikan bantuan dalam menyelesaikan penelitian ini. 


\section{Pustaka}

Ala'raf, H. M. 2017. Pengembangan Media Pembelajaran Matematika Menggunakan Lectora inspire pada Materi Trigonometri untuk Meningkatkan Motivasi Belajar Siswa Kelas X Mia Man Wlingi. Skripsi, tidak diterbitkan, Institut Agama Islam Negeri, Tulungagung.

Burhan, A. V. 2014. Penerapan Model Pembelajaran Air Pada Pembelajaran Matematika Siswa VIII SMPN 18 Padang. Jurnal Pendidikan Matematika, 3, 6-11.

Huda, Miftahul. 2014. Model-Model Pengajaran dan Pembelajaran:Isu-Isu Metodis dan Paradigmatis. Yogyakarta:Pustaka Pelajar.

Hobri, H. 2010. Metodologi Penelitian Pengembangan. Jember: Pena Salsabila.

Ibrahim, N., Ishartiwi. 2017. "Pengembangan Media Pembelajaran Mobile Learning Berbasis Android Mata Pelajaran IPA Untuk Siswa SMP”. Refleksi Edukatika, 8, 81-90.

Junaidi dan Arisna, Y. 2013. "Pengaruh Metode Pembelajaran Kumon Terhadap Peningkatan Hasil Belajar Matematika Siswa Di Kelas VII MTsN Sigli Pada Materi Limas Tahun Pelajaran 2011/2012”. Jurnal Sains Riset, 3, 1-8.

Putri, Rachmawati. 2017. "Implementation Of Kumon Learning Method To Student Learning Independence”. Pancaran Pendidikan. 6. 69-76.

Rochmad. 2012. "Desain Model Pengembangan Perangkat Pembelajaran Matematika". Jurnal Kreano. Vol. 3 No. 1. 59-72.

Safaat, H.N. 2012. Pemrograman Aplikasi Mobile Smartphone dan Tablet PC Berbasis Android. Bandung : Penerbit Informatika.

Setyadi, D., dan Abd. Qohar. 2017. "Pengembangan Media Pembelajaran Matematika Berbasis Web pada Materi Barisan dan Deret”. Kreano, 8, 1-7.

Syita Fatih 'Adna dan Dewi Mardhiyana. 2019. "Pengembangan Bahan Ajar Statistika Penelitian Pendidikan Berbasis Quick Response (QR) Code Sebagai Upaya Meningkatkan Kemampuan Pemahaman Konsep Matematika". Prosiding Seminar Nasional Matematika Dan Pendidikan Matematika (4th SENATIK). 6-15.

Widiawati, N., Sofyan, D.. 2015. "Perbandingan Prestasi Belajar Matematika Siswa antara yang Mendapatkan Metode Kumon dan Metode Konvensional". Jurnal Pendidikan Matematika, 2, 99-110. 